ТЕОРЕТИКО-МЕТОДОЛОГІЧНІ ЗАСАДИ ІДЕНТИФІКАЦІЇ РИЗИКІВ УПРОВАДЖЕННЯ БІЗНЕС-ТЕХНОЛОГІЙ
ПІДПРИЕМНИЦЬКИМИ СТРУКТУРАМИ

\title{
THEORETICAL AND METHODOLOGICAL PRINCIPLES OF RISK IDENTIFICATION OF INTRODUCTION OF BUSINESS TECHNOLOGIES BY ENTREPRENEURIAL STRUCTURES
}

Удк 330.131

https://doi.org/10.32843/bses.62-14

\section{Семенова д.о.}

к.е.н., доцент,

доцент кафредри економіки

та бізнес-технології

Національний авіаційний університет

Semenova Darya

National Aviation University
У статті представлено теоретико-методологічні засади ідентиорікації ризиків упровадження бізнес-технологій підприємницькими структурами. Розглядаючи ризик як співвідношення ймовірності виникнення ризикової ситуації та ії наслідків, що призводить до відхилення фрактичних результатів діяльності від запланованих, доведено необхідність його ідентифрікації проводити з урахуванням не тільки ризикових подій, а й причин їх виникнення, фракторів виникнення ризикових подій, ймовірності та вірогідності настання та наслідків реалізації ризикової події. Запропоновано методологічний підхід, який забезпечує не лише ідентифрікацію ризиків, а й лає змогу координувати процес мінімізації ризиків, підвищення масштабованості та гнучкості, зниження витрат та враховує не тільки планові та прогнозовані значення результативності впровадження бізнес-технологій, а й загальний запланований результат діяльності підприємницької структури. Ураховуючи можливі межі застосування апарату теорії ймовірностей, запропоновано використання теорії марковських процесів із дискретними станами і неперервним часом під час визначення ймовірності зниження результативності $n$-ої бізнес-технології внаслідок настання n-ої ризикової ситуації, відповідно до чого отримано модель визначення кількості рівномірних переходів системи зі стану в стан, урахування якої під час моделювання результативності n-ої бізнес-технології підприємницьких структур забезпечує розширення інструментарію планування і прогнозування ризикових cumyauіŭ.

Ключові слова: бізнес-технологія, підприємницька структура, ризикова ситуація, ризикова подія, фрактор ризику, ймовірність настання ризику, планування, прогнозування.

В cтатье представлены теоретикометодологические основы идентифика- ции рисков внедрения бизнес-технологий предпринимательскими структурами. Рассматривая риск как соотношение вероятности возникновения рисковой ситуации и ее последствий, что приводит $k$ отклонению фрактических результатов деятельности от запланированных, доказана необходимость его идентисиикации с учетом не только рисковых событий, но и причин их возникновения, фракторов возникновения рисковых событий, вероятности наступления и последствий реализации рискового события. Предложен методологический подход, который обеспечивает не только идентифрикацию рисков, но и позволяет координировать процесс минимизации рисков, повышения масштабируемости и гибкости, снижение затрат и учитывает не только плановые и прогнозные значения результативности внедрения бизнес-технологий, но и общий планируемый результат деятельности предпринимательской структуры. Учитывая возможные пределы применения аппарата теории вероятностей, предложено использование теории марковских процессов с дискретными состояниями и непрерывным временем при определении вероятности снижения результативности п-й бизнестехнологии вследствие наступления $n$-й рисковой ситуации, в соответствии с чем получена модель определения количества равномерных переходов системы из состояния в состояние, учет которой при моделировании результативности n-й бизнес-технологии предпринимательских структур обеспечивает расширение инструментария планирования и прогнозирования рисковых ситуаций.

Ключевые слова: бизнес-технология, предпринимательская структура, рисковая ситуация, рисковое событие, фрактор риска, вероятность наступления риска, планирование, прогнозирование.

The article presents the theoretical and methodological principles of identifying the risks of implementing business technologies by business structures. Considering the risk as the ratio of the probability of a risk situation and its consequences, which leads to the deviation of actual results from the planned, proved the need to identify it taking into account not only risk events but also the causes, risk factors, probability and probability of occurrence and the consequences of the implementation of a risky event. A methodological approach is proposed, which provides not only risk identification, but also allows to coordinate the process of risk minimization, scalability and flexibility, cost reduction and takes into account not only the planned and projected values of business technology performance, but also the overall planned result of business structure. Since the process of identifying the risks of the introduction of the $n$-th business technology by the business structure is proposed to be considered as a set of certain sequential actions, respectively, it is logical to build an appropriate functional relationship, which includes research sources of risk situation; occurrence or change of a certain phenomenon or set of circumstances that cause a risky event; identification of risk factors that cause risk situations; the actual risk situation, which we consider as an event that is due to causes and risk factors that may lead to negative or positive consequences; consequences (result) of the risk situation in case of its implementation; the probability of a risk situation, i.e, a quantitative measure of the probability of an event and the vulnerability of the $n$-th business technology to the source of risk. Given the possible limits of the apparatus of probability theory, it is proposed to use the theory of Markov processes with discrete states and continuous time in determining the probability of reducing the effectiveness of $n$-th business technology due to the $n$-th risk situation, respectively, obtained a model for from state to state, taking into account which in modeling the effectiveness of the $n$-th business technology of business structures provides an expansion of tools for planning and forecasting risk situations.

Key words: business technology, business structure, risk situation, risk event, risk factor, probability of risk, planning, forecasting. 
Постановка проблеми. 3 огляду на те, що ризик являє собою співвідношення ймовірності виникнення ризикової ситуації та її наслідків, що призводить до відхилення фрактичних результатів діяльності від запланованих, його ідентиорікація ускладнюється необхідність кількісного вимірювання не тільки власне ризикових подій, а й причин їх виникнення, фракторів виникнення ризикових подій, ймовірності та вірогідності настання та наслідків реалізації ризикової події.

Відсутність єдиних методичних положень щодо ідентифрікації ризиків упровадження бізнес-технологій підприємницькими структурами зумовлює необхідність розроблення та апробації відповідних методологічних основ, які б, своєю чергою, забезпечували не тільки власне ідентифікацію ризиків, яка включає в себе встановлення основних меж управління ризиками, а й сприяли б координації інновацій, мінімізації ризиків, підвищенню масштабованості та гнучкості, зниженню витрат та були передумовою планування та прогнозування не лише результативності впроваджених бізнес-технологій, а й загального запланованого результату діяльності підприємницької структури.

Аналіз останніх досліджень і публікацій. Основні теоретичні аспекти аналізу, оцінки та управління ризиками у підприємництві розглядаються у роботах А. Сміта, Ф.Х. Найта, Й. Шумпетера, Е. Холмса, А.П. Альгіна, І.Т. Балабанова, І.Ю. Івченко, В.В. Вітлінського, В.М. Гранатурова, В.В. Лук'янової, С.І. Наконечного, А.Б. Каменського, О.Л. Устенко, М. Акек, С.С. Осадець та ін. Проте проведені дослідження не дають відповіді на всі питання та не вирішують усього комплексу проблем, пов'язаних з ідентифрікацією ризику.

Постановка завдання. Метою статті $€$ подальший розвиток теоретичних положень, обґрунтування методичних підходів і практичних рекомендацій щодо ідентиорікації ризиків упровадження бізнес-технологій підприємницькими структурами.

Виклад основного матеріалу дослідження. Ризики є невід'ємним складником будь-якої підприємницької діяльності. Тотальність та всеосяжність ризиків за сучасних умов господарювання призвели до появи тверджень про те, що проблема ризику набирає загальноекономічного значення, оскільки ризик сприймається як один із головних чинників сучасного й особливо майбутнього суспільства [4].

Більшість відомих прикладів неефективності систем управління ризиками у цілому та підприємницькими ризиками зокрема, головним чином, зумовлено істотними прорахунками в процесі їх формування, а не лише недоліками, пов'язаними 3 недооцінкою ступеня впливу ризиків [3, с. 55], саме тому актуальним $€$ необхідність розроблення методичних положень щодо ідентифрікації ризиків упровадження бізнес-технологій підприємницькими структурами.

На нашу думку, процес ідентисрікації ризиків упровадження $n$-ої бізнес-технології підприємницькою структурою доцільно розглядати як сукупність певних послідовних дій щодо дослідження джерел появи ризикової ситуації; появи чи зміни певного явища або набору обставин, які зумовлюють ризикову подію; виявлення чинників ризику, що зумовлюють появу ризикових ситуацій; власне ризикової ситуації, яка розглядається нами як подія, яка зумовлена причинами і фракторами ризику, що може призвести до негативних або позитивних наслідків; наслідків (результату) ризикової ситуації в разі їі реалізації; ймовірності настання ризикової ситуації, тобто кількісна міра вірогідності виникнення події та вразливості n-ої бізнес-технології до джерела ризику, що дає змогу представити процес ідентиорікації ризиків упровадження бізнес-технологій підприємницькими структурами у вигляді такої функції:

$R I=\int(C R ; R E ; R F ; R S ; C R S ; P R E ; V S R) \rightarrow \min$,

де RI - ідентиорікація ризиків (risk identification), $\mathrm{CR}$ - причини ризику (causes of risks), RE - ризикова подія (risky event), RF - фрактори ризику (risk factors), RS - ризикова ситуація (risky situation), CRS - наслідки ризикової ситуації (consequences of the risk situation), PRE - ймовірність виникнення ризикової події (the probability of a risky event), VSR - вразливість до джерела ризику (vulnerability to the source of risk).

Процес ідентиорікації ризиків упровадження n-ої бізнес-технології підприємницькою структурою представлено на рис. 1.

Водночас ризик - це не лише результат певних дій чи ймовірність настання певної події, сутність ризику розкривається також і через причини його виникнення (джерело ризику). Причиною ризику $€$ певна подія, ймовірність реалізації якої можна визначити, а ось час та місце її виникнення точно визначити неможливо. Вона зумовлена специфікою ринкових відносин, впливом зовнішніх чинників (навколишнього середовища) та внутрішніх чинників (у т. ч. суб'єктивних особливостей осіб, що приймають рішення) [1].

Математично ймовірність відображається так [1]:

$$
P(A)=m / n,
$$

де $P(A)$ - ймовірність настання події $A ; m$ - кількість можливих результатів, за яких настає подія $A$; $n$ - загальна кількість результатів.

При цьому наслідки - це результати подій, які впливають на досягнення цілей. Подія може призводити до низки наслідків. Наслідки можуть бути визначеними або невизначеними, можуть справляти позитивний чи негативний вплив на досягнення цілей. Наслідки можуть бути виражені кількісно або якісно. Початкові наслідки можуть 


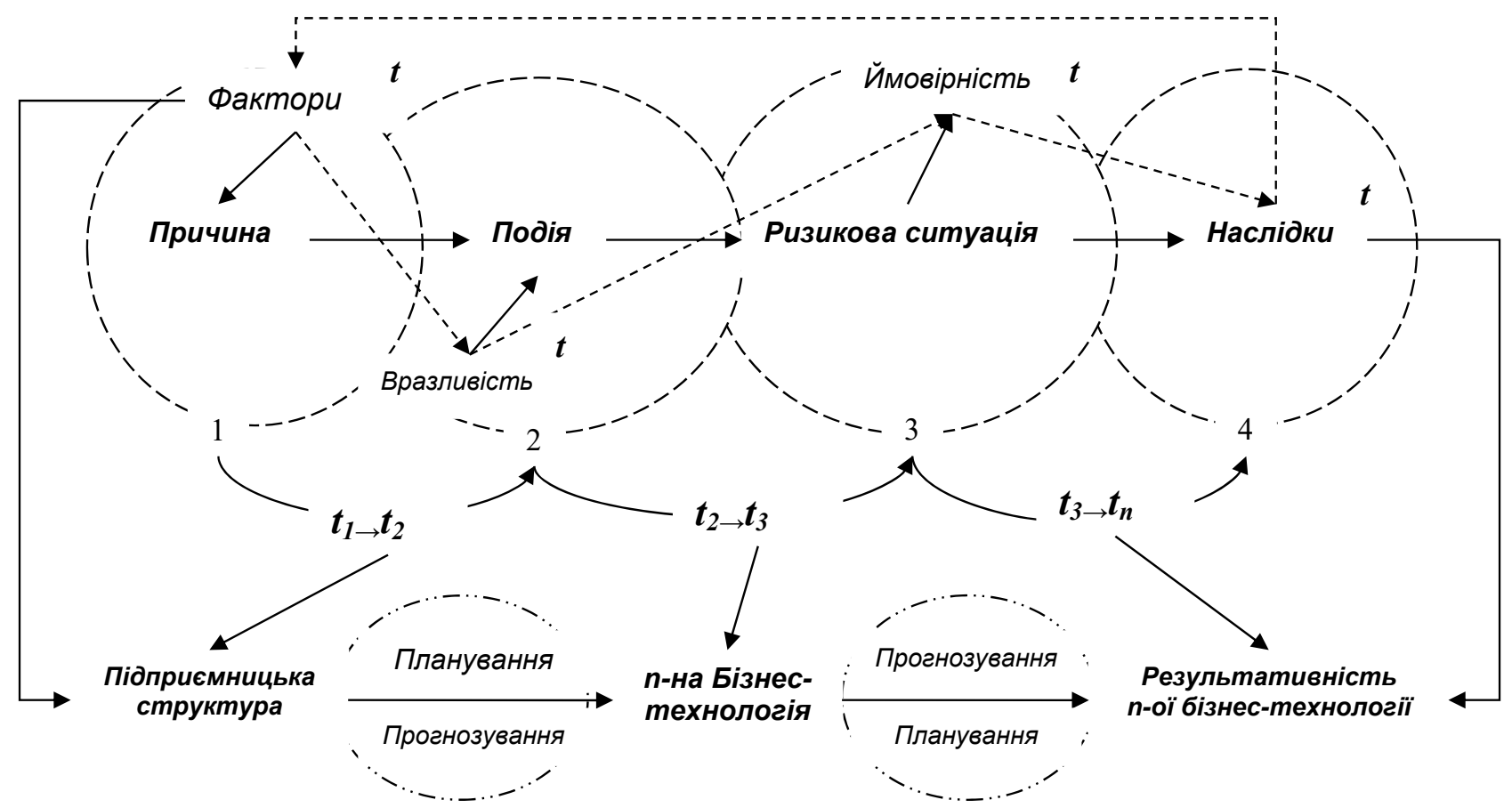

Рис. 1. Процес ідентифікації ризиків упровадження n-ої бізнес-технології підприємницькою структурою

\author{
Джерело: розробка автора
}

спричиняти ланцюг вторинних наслідків, тобто призводити до «ефректу доміно» [2].

3 огляду на те, що в науковій літературі тією чи іншою мірою досліджено питання як якісного, так і кількісного оцінювання ризиків, на нашу думку, особливої уваги потребує дослідження можливостей зміни результативності n-ої бізнес-технології внаслідок настання $n$-ої ризикової ситуації, що дасть змогу не лише підвищити ефективність ризик-менеджменту, а й розширить інструментарій планування і прогнозування ризикових ситуацій під час упровадження інноваційних бізнес-технологій підприємницькими структурами.

Ураховуючи можливі межі застосування апарату теорії ймовірностей, на нашу думку, саме використання теорії марковських процесів із дискретними станами і неперервним часом дає змогу визначити ймовірність зниження результативності $n$-ої бізнес-технології внаслідок настання $n$-ої ризикової ситуації.

Виходячи 3 вищезазначеного, доцільно припустити, що переходи системи $S$ (результативність $n$-ої бізнес-технології) зі стану $S_{i}$ у стан $S_{j}$ відбуваються під впливом деякого потоку подій, у нашому випадку - n-ої ризикової ситуації.

Процес Маркова з дискретними станами і неперервним часом є однорідним у разі, якщо для будьяких $i$ та $j, i \neq j, i=1,2, \ldots n, j=1,2, \ldots n$, щільність ймовірності переходу $\lambda_{j l}(t)$ системи зі стану $S_{i}$ у стан $S_{j}$ не залежить від часу $t$, тобто $\lambda_{j l}(t)=\lambda_{j l}=$ const. Оскільки перехід можливий у будь-який випадковий момент часу, то ми маємо справу з випадковим марковським процесом із безперервним часом.
Нехай система $S$ може перебувати у $n$ станах $\mathrm{S}_{1}$, $S_{2}, \ldots, S_{n}$. Переходи зі стану в стан можливі тільки в моменти часу $t_{1}, t_{2}, \ldots, t_{k}$, назвемо ці моменти часу кроками. Будемо розглядати випадкові процеси в системі $S$ (результативність $n$-ої бізнес-технології) як фрункцію цілочисельного аргументу $1,2, \ldots, k$, де аргументом є номер кроку:

$$
\mathrm{S} 1 \rightarrow \mathrm{S} 2 \rightarrow \mathrm{S} 3 \rightarrow \mathrm{S} 2 .
$$

Домовимося, що $\mathrm{S}_{\mathrm{i}}{ }^{(\mathrm{k})}$ - подія, що полягає у тому, що після $k$ кроків система знаходиться у стані $S_{i}$. За будь-якого $k$ події $S_{1}{ }^{(k)}, S_{2}{ }^{(k)}, \ldots, S_{n}{ }^{(k)}$ утворюють повну групу подій і $€$ несумісними. Процес у системі можна уявити як ланцюжок подій.

Така послідовність називається марковським ланцюгом, якщо для кожного кроку ймовірність переходу з будь-якого стану $S_{i}$ у будь-який стан $S_{j}$ не залежить від того, коли й як система прийшла у стан $S_{i}$.

Нехай у будь-який момент часу після будь-якого k-го кроку система $S$ може знаходитися в одному зі станів $S_{1}, S_{2}, \ldots, S_{n}$, тобто може статися одна подія 3 повної групи подій: $\mathrm{S}_{1}{ }^{(\mathrm{k})}, \mathrm{S}_{2}{ }^{(\mathrm{k})}, \ldots, \mathrm{S}_{\mathrm{n}}{ }^{(\mathrm{k})}$, зокрема:

$$
\begin{aligned}
& P_{1}^{(1)}=P\left(S_{1}{ }^{(1)}\right) ; P_{2}^{(1)}=P\left(S_{2}^{(1)}\right) ; \ldots ; P_{n}^{(1)}=P\left(S_{n}{ }^{(k)}\right) ; \\
& P_{1}^{(2)}=P\left(S_{1}{ }^{(2)}\right) ; P_{2}{ }^{(2)}=P\left(S_{2}^{(2)}\right) ; \ldots ; P_{n}^{(2)}=P\left(S_{n}^{(2)}\right) \text {; } \\
& P_{1}{ }^{(k)}=P\left(S_{1}{ }^{(k)}\right) ; P_{2}{ }^{(k)}=P\left(S_{2}{ }^{(k)}\right) ; \ldots ; P_{n}{ }^{(k)}=P\left(S_{n}{ }^{(k)}\right) \text {. }
\end{aligned}
$$

Тобто для кожного номера кроку виконується умова:

$$
P_{1}(k)+P_{2}(k)+\ldots+P_{n}(k)=1 .
$$

Також процеси у системі можна зобразити у вигляді послідовності станів: $\mathrm{S}_{1}, \mathrm{~S}_{3}, \mathrm{~S}_{2}, \mathrm{~S}_{2}, \mathrm{~S}_{3}, \mathrm{~S}_{5}$, $\mathrm{S}_{6}, \mathrm{~S}_{2}$, при цьому ймовірність стану на $(k+1)$-му кроці залежить тільки від стану на $k$-му кроці. 
Для будь-якого кроку $k$ існують якісь імовірності переходу системи з будь-якого стану в будь-який інший стан, назвемо ці ймовірності перехідними ймовірностями марковського ланцюга. Деякі із цих ймовірностей будуть рівні 0, якщо перехід 3 одного стану в інший неможливий за один крок.

Нехай є однорідний марковський ланцюг та система $S$ має $n$ можливих станів: $S_{1}, \ldots, S_{n}$. Нехай для кожного стану відома ймовірність переходу в інший стан за один крок, тобто $P_{i j}\left(\right.$ з $S_{i}$ в $S_{j}$ за один крок), тоді ми можемо записати перехідні ймовірності у вигляді такої матриці:

$$
\|P i j\|=\left(\begin{array}{ll}
P_{11} & P_{12}-P_{1 n} \\
P_{21} & P_{22}-P_{2 n} \\
P_{n 1} & P_{n 2}-P_{n m}
\end{array}\right) .
$$

По діагоналі цієї матриці розташовано ймовірності того, що система переходить зі стану $S_{i}$ у той же стан $S_{i}$.

Користуючись уведеними раніше подіями $\mathrm{S}_{1}{ }^{(k)}$, $S_{2}{ }^{(k)}, \ldots, S_{n}{ }^{(k)}$, можна перехідні ймовірності записати як умовні ймовірності:

$$
P i j=P\left(S_{j}^{(k)} / S_{i}^{k-1}\right),
$$

Очевидно, що сума членів $P i j=P\left(S_{j}^{(k)} / S_{i}^{k-1}\right)$, в кожному рядку матриці (2) дорівнює одиниці, оскільки події $S_{1}{ }^{(k)}, S_{2}{ }^{(k)}, \ldots, S_{n}{ }^{(k)}$ утворюють повну групу несумісних подій.

Основними станами системи «результативність n-ої бізнес-технології» $€$ :

$S_{n}$ - «впровадження $n$-ої бізнес-технології»;

$S_{1}$ - «підвищення результативності $n$-ої бізнестехнології»;

$S_{2}$ - «зниження результативності $n$-ої бізнестехнології»;

$S_{3}$ - «корегування $n$-ої бізнес-технології».

Перелік варіантів ймовірності циклічних переходів $€$ таким: а - ймовірність переходів системи «результативність $n$-ої бізнес-технології» від стану «впровадження $n$-ої бізнес-технології» 3 метою їх застосування до стану «корегування $n$-ої бізнестехнології»; b - ймовірність переходів від стану «корегування $n$-ої бізнес-технології» до стану «результативності $n$-ої бізнес-технології»; с - ймовірність переходів системи «результативність n-ої бізнес-технології» від стану «підвищення результативності $n$-ої бізнес-технології» до стану «корегування $n$-ої бізнес-технології»; d - ймовірність переходів від стану «корегування $n$-ої бізнестехнології» до стану «зниження результативності n-ої бізнес-технології»; е - ймовірність переходів системи «результативність $n$-ої бізнес-технології» від стану «впровадження $n$-ої бізнес-технології» до стану «зниження результативності $n$-ої бізнес-технології»; f - ймовірність переходів від стану «впровадження $n$-ої бізнес-технології» до стану «зниження результативності $n$-ої бізнестехнології»; $g$ - ймовірність переходів системи «результативність $n$-ої бізнес-технології» від стану «підвищення результативності $n$-ої бізнестехнології» до стану «впровадження $n$-ої бізнестехнології»; h - ймовірність переходів від стану «зниження результативності $n$-ої бізнес-технології» до стану «підвищення результативності $n$-ої бізнестехнології»; і - ймовірність переходів системи «результативність $n$-ої бізнес-технології» від стану «підвищення результативності $n$-ої бізнестехнології» до стану «зниження результативності n-ої бізнес-технології».

Знаючи матрицю перехідних ймовірностей і початковий стан системи «результативність $n$-ої бізнес-технології», можна знайти ймовірності станів $P_{1}^{(k)}, P_{2}^{(k)}, \ldots, P_{n}^{(k)}$ після будь-якого $k$-го кроку. Оскільки в початковий момент часу система знаходиться в стані $S_{m}$, тоді для $t=0$.

$$
P_{1}(0)=0, P_{2}(0)=0, \ldots, P_{m}(0)=1, \ldots, P_{n}(0)=0
$$

Оскільки зі стану $S_{m}$ система перейде в стан $S_{1}$, $S_{2}$ і т. д. $з$ вірогідністю $P_{m 1}, P_{m 2}, \ldots, P_{m m}, \ldots, P_{m n}$, тоді після першого кроку ймовірності дорівнюватимуть:

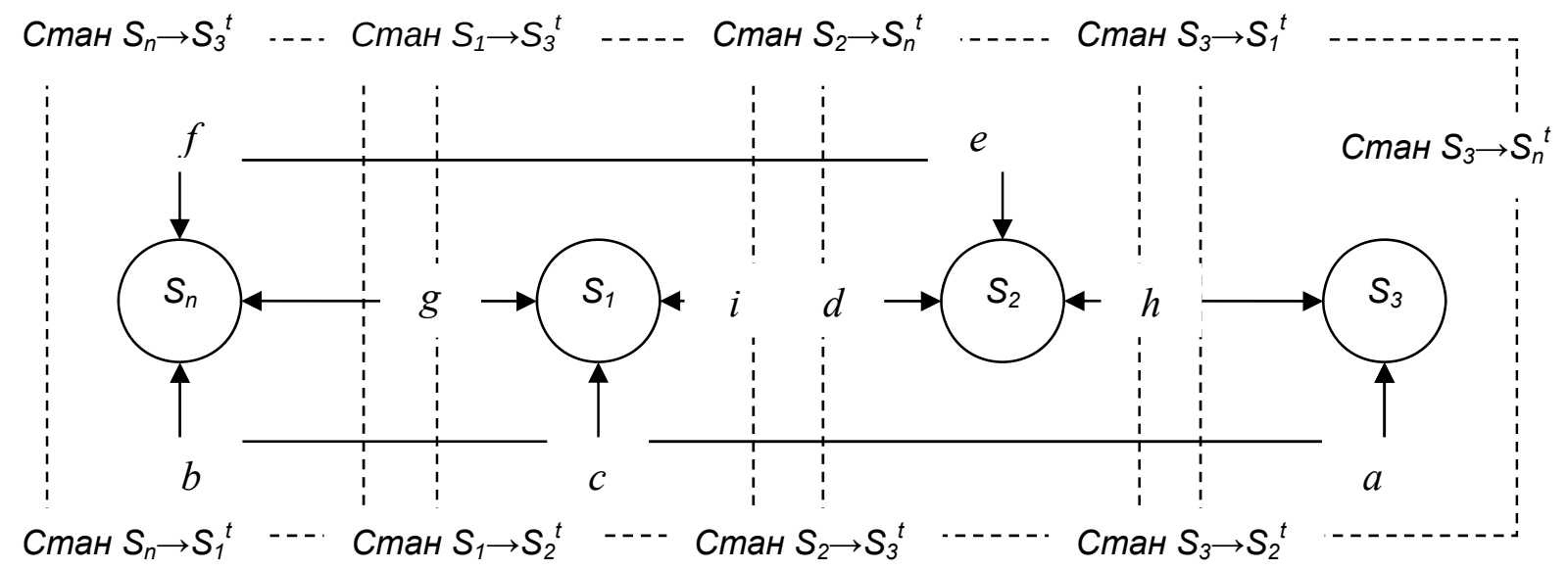

Рис. 2. Граф переходів основних станів системи «результативність n-ої бізнес-технології» і багаторазових переходів системи у ці стани 


$$
P_{1}(1)=P_{m 1} ; P_{2}(1)=P_{m 2}, \ldots, P_{n}(1)=P_{m n} .
$$

Знайдемо ймовірності стану після другого кроку: $P_{1}(2), P_{2}(2), \ldots, P_{n}(2)$. Будемо обчислювати ці ймовірності за фрормулою повної ймовірності 3 гіпотезами:

$$
P(A)=\sum_{i=1}^{n} P\left(H_{i}\right) \cdot P\left(A / H_{i}\right)
$$

Гіпотезами будуть такі твердження:

- після першого кроку система була у стані $S_{1}-H_{1}$;

- після другого кроку система була у стані $\mathrm{S}_{2}-\mathrm{H}_{2}$;

- після $n$-го кроку система була у стані $S_{n}-H_{n}$.

Ймовірність будь-якого стану після другого кроку:

$$
P_{i}(2)=\sum_{j=1}^{n} P_{j}(1) P_{j i}, \quad i=\overline{1, n} .
$$

У фрормулі (5) підсумовуються всі перехідні ймовірності $P_{i j}$, але враховуються тільки відмінні від нуля. Ймовірність будь-якого стану після $k$-го кроку:

$$
P_{i}(k)=\sum_{j=1}^{n} P_{j}(k-1) P_{j i}, \quad i=\overline{1, n} .
$$

Таким чином, ймовірність стану після $k$-го кроку визначається за фрормулою (6) через ймовірності $(k-1)$-го кроку, що доводить умови рівноймовірних переходів системи зі стану у стан та підтверджує правильність твердження.

Застосування апарату теорії ймовірностей, зокрема використання теорії марковських процесів, дає змогу визначити не лише кількість рівномірних переходів системи зі стану у стан, а й представити результативність упровадження n-ої бізнес-технології з урахуванням впливу ризиків у такому вигляді:

$$
R_{\text {БTRI }}=\left(\frac{(C R * R F)+(R E * V S R)+(R S * P R E)+C R S}{K_{S n-S 3}}\right) *\left(1 \frac{1}{n}\right),
$$

де $R_{\text {БтRI }}$ - результативність $n$-ої бізнес-технології підприємницьких структур, $\mathrm{K}_{\mathrm{Sn}-\mathrm{S} 3}$ - кількість рівномірних переходів системи зі стану у стан, $(1-1 / n)$ - ваговий коефіцієнт, який ураховує ризики (n) за досягнення необхідного рівня результативності $n$-ої бізнес-технології.

Висновки 3 проведеного дослідження. Запропонований підхід до ідентифрікації ризиків упровадження бізнес-технологій підприємницькими структурами ґрунтується на уявленні ризиків як певної фрункціональної залежності, дотримання якої дає змогу враховувати вплив загроз та максимізувати вигоди від використання $n$-ої бізнес-технології, зменшити рівень невизначеності настання ризикової ситуації. Окрім того, на основі дискретних марковських процесів отримано модель визначення кількості рівномірних переходів системи зі стану у стан, урахування якої під час моделювання результативності $n$-ої бізнес-технології підприємницьких структур забезпечує розширення інструментарію планування і прогнозування ризикових ситуацій.

\section{БІБЛІОГРАФІЧНИЙ СПИСОК:}

1. Економічний ризик: методи оцінки та управління : навчальний посібник / Т.А. Васильєва та ін. ; за ред. Т.А. Васильєвої, Я.М. Кривич. Суми : ДВНЗ «УАБС НБУ», 2015. 208 с.

2. Спроба локалізації ISO GUIDE 73:2009 «RISK MANAGEMENT - VOCABULARY» / B. Moxop та ін. Ukrainian Scientific Journal of Information Security. 2012. № 2(18). C. 12-22.

3. Пильнова В.П., Гавриш О.М., Капелюшна Т.В. Формування системи управління підприємницькими ризиками. Інвестиції: практика та досвід. 2020. № 24. C. 51-57.

4. Шкарлет С.М., Шкарлет С.М., Ільчук В.П. Інноваційний розвиток підприємства : навчальний посібник. Чернігів, 2015. 307 с.

\section{REFERENCES:}

1. Vasylieva T.A. (2015) Ekonomichnyi ryzyk: metody otsinky ta upravlinnia [Economic risk: methods of assessment and management]. Sumy: DVNZ "UABS NBU". (in Ukrainian)

2. Mokhor V., Bohdanov O., KrukO., Tsurkan V. (2012) Sproba lokalizatsii ISO GUIDE 73: 2009 "RISK MANAGEMENT - VOCABULARY" [Attempt to localize ISO GUIDE 73: 2009 "RISK MANAGEMENT - VOCABULARY"]. Ukrainian Scientific Journal of Information Security, vol. 2 (18), pp. 12-22.

3. Pylnova V.P., Havrysh O.M., Kapeliushna T.V. (2020) Formuvannia systemy upravlinnia pidpryiemnytskymy ryzykamy [Formation of a business risk management system]. Investytsii: praktyka ta dosvid, vol. 24, pp. 51-57.

4. Shkarlet S.M., Shkarlet S.M., Ilchuk V.P. (2015) Innovatsiinyi rozvytok pidpryiemstva [Innovative development of the enterprise]. Chernihiv. (in Ukrainian) 